\title{
Women Subordination Through Patriarchal Discursive Practices Regarding Inheritance
}

\author{
Rabbia Aslam \\ Department of Women's Studies \\ Allama Iqbal Open University, Islamabad
}

\begin{abstract}
This paper examines socio-cultural practices that deter women from claiming their rights to inherit family property although it is given to them by their religion and is upheld by law. The first section of the research is a brief discussion of research setting and methods. The second section analysis of the data depicts discursive practices such as, patriarchal socialization, decision-making, and customs. It particularly looks at dowry as a custom and as a tool for maintaining women's subordination. The third section examines the legal hindrances women face to get their inheritance. Finally, this paper presents a brief appraisal of patriarchy as it works for the perpetuation of women's subordination.

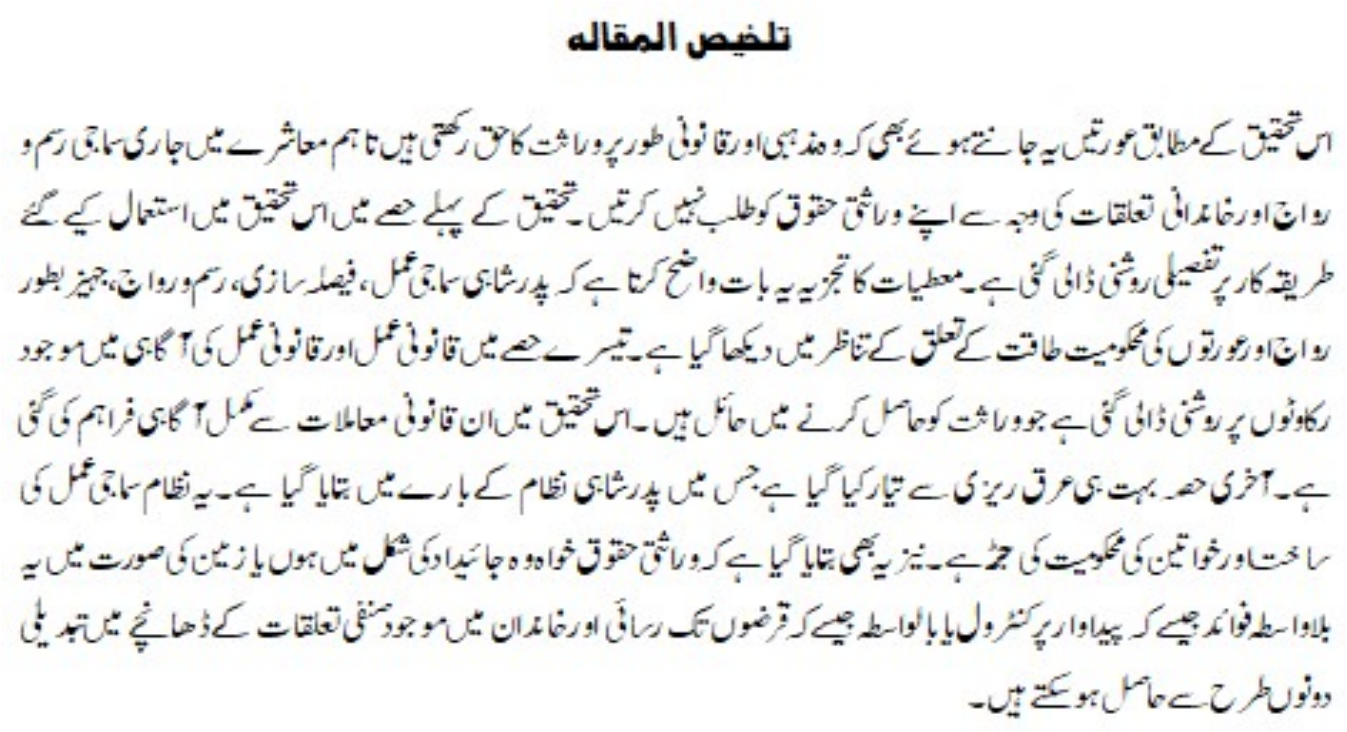

\section{Introduction}

Women subordination through patriarchal discursive practices regarding inheritance is a case study of village in Tehsil Bhalwal, District Sargodha, in the Punjab. The study aims to investigate women's awareness about their property rights and to find out about social pressures for transferring their share to male members of their family. The sample consists of ten married women. The data was collected through semi-structured interview guide. The data revealed that most of the women do not have awareness about their rights and live a subordinated life under the 
influence of fathers, brothers and husband. For the sake of keeping relationships, protection and support from the parental family, these women have been denied access to their share of property (which in most cases is either an agricultural land or parental home).Women also know that religiously and legally they have a right to inherit property. The perception of women's place in the family and the prevalent social structure that perpetuates unequal gender enhance women's passive and marginalized status. So even if women know about their religious and legal underpinnings of inheritance it is not beneficial for them. Women's legitimate share in landed property can prove to be the single most critical entry point for women's empowerment. However females are denied this right generation after generation.

\section{Research Setting and Method}

Developing a holistic feminist research approach qualitative research methodology was adopted by using interview guide as a tool to interview the participants of the research. Feminist research deals with the creation of new knowledge, which addresses aspects of women's oppression and subordination in different societies (Hesse, Biber, 2007). Not only women become starting point for doing feminist research but more importantly feminist research places emphasis on gender power relations (Siagol, 1993).

The sample of the research is representative of the population in the Punjab province. The village Bhalwal 4SB basically comprises of the ethnic group of Jats who are farmers owning land. The main rationale behind the selection of this village was that no study of this kind has been conducted in this area. Also the area was selected as convenient site because the researcher belongs to the area. The cases were selected through the list of families who own 20-acre land from the village Patwari. ${ }^{1}$ The interviews were conducted in the Urdu language. The researcher took written notes during the interview with the respondents.

The age group of the selected sample was 30 to 50 years and their education level was between middle to graduation. The researcher used unstructured interview guide based on the objectives of the study. During the interviews spontaneously emerging questions were also dealt which supplemented data (Oakley, 1981; Singleton, 1988).

The qualitative data obtained through semi-structured interview guide and observations were presented through systematic and analytical description of the facts. Data analysis is an activity based on a cognitive mode different from data gathering; reflective rather active, solitary rather than interaction patterns and basic theme. The themes based on the objectives were subcategorized by dividing them in to sub-headings. In course of data analysis themes were finally organized into relevant categories.

\section{Analysis and Discussion}

The analysis demonstrates that the knowledge generated from experiences has depicted the 
inequalities and injustice continued by the family (Hardiy, 2004). The data analyses not only fulfilled the objectives of the research, but it also initiated new questions for further studies. It was very interesting to note that the respondents of this research were aware of their rights and shared their feelings frankly sometimes they were audacious in their thoughts but hopeless to take any action.

\section{Patriarchal Socialization}

Patriarchy is rooted in the social fabric of the area as it is elsewhere in the world. The norms strengthened by cultural, religious, and political trends turn into oppression and marginalization of the female population.

Papanek rightly argues that for the study South Asian woman the single most important aspect is their social context (1982). It is important to understand patriarchy as a system of social structures and practices in which men dominate, suppress and exploit women. Interestingly women accept it willingly and give up their rights and those strategies that ensure their protection.

Thus patriarchy is historically rooted in our social structure to such a degree that it has become part of the socialization of men and women. Patriarchal institutions assign different roles and responsibilities to both men and women. Women are taught to bear every oppression for being a good daughters, sisters and wives. One of the respondents put this brutal practice in simple words and said, "it is women's socialization that a girl should obey every rule laid down by a brother, a father and a husband."

In our male dominated society women do not feel secure. A man threatens his wife by using the word of talaq (divorce). One of the respondents reported that, "men use the power of the word talaq. men and women, both, destroy their married life, but in anger a man does not consider it, what he is going to do"'; most of the respondent said that a man is hakim. ${ }^{2}$ When they become hakim women are suppressed and forced to obey their order. The families' structure strengthens their power. The word family originally meant the slave belonging to the one man (Angel, 1972).

Men are powerful; they are like a horse that cannot sit in any one position for a long time. One of the respondent reported that, "Men are Akar khan', 3. The power structure justifies inequalities in the society. Interviewee's responses depict patriarchal socialization of this village, which reinforced the patriarchy in many shapes as shall be depicted in the subsequent arguments as well.

\section{Decision-Making Power}

The institution of patriarchy and power structure impede women to play an active role in decision-making. In patriarchal family structures decision-making power in important matters is not shifted to women of the family. Moreover men devalue women's knowledge and women's 
perspective. When asked about the decision-making one of the respondents reported that, "man thinks he has more wisdom and knowledge and he can take better decisions'. In the village most of the women were limited to private sphere and internalized the concept that their only duty is to perform household chores. Women are exploited and they make sacrifices through out their lives before marriage for their father and brother and after marriage for the husband and children. Most of the respondents reported that, "women are dependent on the mercy of their husbands, fathers and brothers in all affairs.' According to Marx (2002) private sphere of life exclude women from the public domain of life they are only limited to house hold boundaries. Men think that women should remain in chadar and char dawari. ${ }^{4}$ Exclusion of women from public sphere besides, lack of education, socialization and confidence, impinges their effectiveness in public sphere. They are limited within four walls of the house having low self-esteem. Eight out of the ten respondents reported that they have no say in the education of their children. But some women shared with the researcher that with the passage of time sometimes they are allowed to decide about their children's marriage proposals.

It is rooted in our societal structure that women can only show acceptance to the decision of men. We always involved in process of acceptance and rejection (Labov, 1978). The interviewees of this research in confirmed that it is the men in their families who take major decision and they do not have any say. Men think that they are accepted in every role and authority and always consider themselves wise and decision makers. The norms and processes involved in social, political, economic and cultural practices legitimize male hegemony in the society (Shaheed, 1998).

\section{Internalization of Values and Behaviors}

Generation through generation women has internalized the values and behavior of not asking for their rights, especially their right to property if any. If they dare that means they are challenging the relationships and loose trust of the family. To the recurring question of why women accept and facilitate in reinforcing oppression, answer tend to be unconvincing; the most acknowledged one being that they have been socialized into accepting discrimination through the process of internalization of norms that discriminate them (Dube, 1988).

Women think that willingly they do not demand their rights, but it is actually internalization. It is not willingness it is a hidden pressure, which women have internalized leading to establish patriarchal way of thinking, both in values and behaviour (Foucault, 1980). Internalization of values and behaviors force women to abandon their rights to assure their future protection. It is true that rural women are suppressed that is why they do not demand their rights. Although they know the worth of the property yet, they do not demand (Hassan, 2001). In patriarchal families husbands and fathers have absolute control over the lives and property of all the members of the family and out of fear, love, and oppression women do not have the courage to ask for their due rights. 


\section{Education}

Women have limited knowledge about their property rights. One of the respondents when asked about her property rights said, "education gives awareness to women and tells them what is right and what is wrong". Those who are educated they are subordinated in different way, because women subordination has existed through generations (Bhasin, 2000). The respondents of this study were reasonably educated but perhaps education does not guarantee acquiring of rights as argued by Bhasin that even educated women are also subordinated (Bhasin, 2000). One of the respondents reported that, "in our times, people do not give importance to the education especially for girls; now people give importance to education for both boys and girls". They said that after all, women have to indulge in household chores. That is why to get education is not necessary for women. Right of education has come their way due to social changes and opening of opportunities in the village. So if they are being educated it is routine matter which is not shaking the institution of patriarchy.

\section{Customs}

With the passage of time, customs and values have been transmitted through generations which also situate unseen pressure within every family. Most of the interviewees expressed that, "our mother did not demand her property rights, therefore, we also do not demand ours, therefore it has become a reet', 5

Women thus live their lives by honouring family traditions. It is justified in the name of the tradition. Bordieu, a French sociologist, used the term "Doxa" 6 for traditions which means that those rules which are not open for questioning, are unnamed, no body can challenge them, and are justified in the name of tradition (Bordieu, 1977 as cited in 1989).

\section{Dowry as a Custom}

Dowry in Pakistani society is a vital part of the marriage custom. Most often parents give dowry to their daughters which are beyond their means. There are overt and covert forms of negotiations concerning dowry. A daughter is given dowry as an all times gift and a share from the family assets. Indirectly at the time of her marriage she is made to understand - do not look back for material support, especially for any share in her parents' or brothers' property. Dowry is, thus, a justification of deprivation of their property rights. Women know that parents give dowry to their daughters, and then they have no claim and share in land or other property. It is also observed in few cases that those who do not get dowry they fight for the property. As one of the respondent said that' "some times it happens that those who cannot afford to give dowry to their daughters and later if on the insistence of in-laws she demands for her share in the property, then male siblings mind it. And the women have no security to keep their marriage intact.' Dowry, the financial burden has been employed as a convenient excuse for denying women's share in inheritance which is also an Islamic right (sura 4:7, 11-12, 176). It is generally argued that women actually receive 
their share of inheritance in the form of dowry. Women are thus caught in the vicious cycle, denied access to economic independence they find themselves subordinate first to their, father, brother and following their marriage to the husband (Ulfat, 2007).

In most of the cases respondents told us that 'parent's say that they give dowry and also support daughters through out their married life, and therefore there remains no share of the land etc. for them. Men deprived women from their property rights, as control over material resources is a male prerogative for maintaining their honours in biradri. One of the respondents reported that, "I have seen in my family that when a sister was claiming for her property right the brother told her 'I will give you money but you have to leave your property rights, because it is a matter of honor in our biradr " ." Male members of the family exploit their rights by impinging female rights and gain empowerment to satisfy their macho institutions. In patriarchal structure the pressure of the families victimized women and dowry is one of those structures (Sharma, 1984).

\section{Dynamics of Power Relations/ Gender Roles}

In Pakistani families kinship system and relationships are strong. Women are leading their life by maintaining their family relations. In building up families' values and relations women lose their own identity. In spite of having rights to parental property, women chose to give up their claim in order to maintain their family ties. Women do not want to end their blood relations. The concern here appears to be not merely economic but also ideological, involving male fears of how gender relations might be altered if women have land. This especially affects women's access to economic independence and empowerment. First, it means that a brother's potential support is important not just economically but also socially. Brothers can be critically important as social mediators not only in the absence of adult sons and husband, but also if women wish to undertake transactions, independent of their martial homes. Second, these restrictions affect women's access to legal information - a crucial prerequisite for exercising their legal rights.

There are processes by which relations involving domination and subordination are produced, reproduced and transformed (Davis, 1991). The women respondents revealed that though they know their rights, but there is no worth of women's concerns. One of the respondents expressed that, "land is considered more important; man considers land like his mother land and does not want to distribute it". Women who give up their rights to hold property realize that their male relatives hardly appreciate what they did for them. Family relations remain strained as their brothers and their wives dislike their presence. One of the respondents reported that, "daughters leave their share of millions, but after the death of their parent's, brothers do not full fill their responsibilities; they have no affection for us".

Another respondent said that, "sacrifice is the other name for women". Parents and relatives force women to leave their right. They put case of $s h u f a^{8}$ on women. Women know worth of material resources. Women know that material resources like money and property will support them in time 
of trouble. One of the respondents reported that, "if a woman has property, then her son and daughter- in-laws will take care of mother in lust of money. Now the big relation of man is money'. The threat of women gaining power through property ownership makes society frown upon women who go ahead to acquire property of their own and as Indrani interprets they are not considered "Proper" "women. Seema and Sharma (2006) describe that the emotional strength of these responses suggests that male heirs were unlikely to relinquish their privileges easily. Not surprisingly, male relatives of potential female heirs began to take pre-emptive steps to circumvent the right of women especially of daughters and sisters.

\section{Legal Prevention to Get Property Right}

Apart from the attitude of kin, a significant determinant of women's ability to exercise their legal rights is the male bias in administrative and judicial bodies and process. Although these bodies differ some what in their membership composition and the level at which they operate, a common feature is their exclusion of women. Women have little say either in framing the rules made by these councils or in the process by which these rules are enforced. Basically this exclusion means that disputes which involve women are settled by male authority and male made rules (UNDP, 2007).

Women know that legally they have rights, but they do not practice them. First, the legal process is so lengthy. Second, women face criticism and abuses from the society, especially from the men. So they move back from their right. Several legal complications exist in Pakistani society. The data analysis shows that there is lack of education and awareness regarding basic rights of women. On the other hand, women know that to get property is Islamic and is a legal right of women. As one respondent shared that, "my husband is a lawyer. One day I found a book on women's rights amendments. When my husband saw this book in my hand, he snatched it from my hands, and said what was I looking for? He said,

'You have no need to study it'. I asked why and he said if women know their rights then it will be dangerous for men, and also said, educated wife is a great loss for a husband.

Non availability of inadequate support structures for women's protection is another cause which prevents women from claiming their property rights. Women are always afraid of physical threats and therefore, they willingly leave their rights and constantly assets those strategies that will ensure their protection (Walby, 1997). Medhi's (2006) comparative study in the four provinces of Pakistan revealed that women do not have awareness about legal procedures, legal matters are considered domain of men. Even the legal system of the country is gender biased.

According to the respondents, now a-days, they have enough exposure to media and are gaining access to information and knowledge. They were well aware of the fact that in 2006, "women protection Bill" has passed. Women are getting awareness about their rights. Two of my 
respondents out of ten reported that, they want to know about women's rights. The reason they gave was that though they could not get their rights but they will make efforts for their daughters to have their rights.

Non availability of inadequate support structures for women's protection is another cause which prevents women from claiming their property rights. Women are always afraid of physical threats and therefore, they willingly leave their rights and constantly assets those strategies that will ensure their protection (Walby, 1997). Medhi's (2006) comparative study in the four provinces of Pakistan revealed that women do not have awareness about legal procedures, legal matters are considered domain of men. Even the legal system of the country is gender biased. There is gambit of discursive practices which inhibited women to get their rights. The legal situation of women is primarily a human rights concern. Deprivation of the rights of any class of the society, denial of their equal status and discrimination are the matters that fall within the area of human rights, and while women may be the direct victims of such discrimination the indirect result is that the whole society undergoes dispossession and a society must learn to view this issue from the perspective of social justice and not merely from the view point of assertion of rights (Zafar, 1991).

The state sees it as a 'private concern' vis-à-vis inheritance, seeing no bearing on its land reforms and redistribution policies. Religious parties, that undertake the responsibility of implementing the Shariah law in Pakistan, ignore this aspect too. Afkhami, writing in another context rightly observed that the landed classes' encounter with land fragmentation and inefficiency, and other national and local power holders ensure that such claims are denied moral legitimacy, and when made are met with violence (Afkhami,1995).

\section{Conclusion}

The present analysis indicates that today change will require simultaneous struggle for property, for the norms governing gender roles and behaviour and towards gender sensitization of public decision-making authorities. It will mean contesting the existing hierarchical character of gender relations, within and outside the household, based on highly unequal access of women and men to economic, political and social power.

Patriarchy is grounded in the socialization process due to which women's subordination is rooted in their lives. The findings of this research show that women are unaware of their basic rights. They think that their rights are what their parents tell them. Thus, their parent's training and socialization tell them about their limits. Moreover, women consider performance of house hold chores as their only duty. The village women do not even know about the concept of individual rights. In building up of family and values they lose their own individual identity and rights. In addition to that, this research found that dowry is considered as an alternative for property. Women's right to property is compensated through dowry. However in some cases they neither get the dowry nor the property. 
Finally, it should be noted that men and women are naturally different; their characters and roles in society are created by customs and not by nature. Customary practices get reinforced by social structures and restrict women's mobility, keep them secluded and deny rights which have no basis in law but often have primacy over it. The constraints identified by this research show that rural women's struggle for effective land right will not be an easy one. The perception of women's place in family and the prevalent social structures that perpetuate unequal relationships and prevent the passive and marginalized status needs to be understood in the correct perspective if one has to evolve strategies for addressing the gender inconsistencies.

\section{End Notes:}

${ }^{1}$ Who deals with land documentation/record.

${ }^{2}$ Hakim mean ruler

${ }^{3}$ Means to be rude

${ }^{4}$ Means to be confined in four walls of the house

${ }^{5}$ Reet means custom or tradition

${ }^{6}$ Tradition

${ }^{7}$ Kinship family system

${ }^{8}$ Customary practice about sharing of home or Property by neighborhood right

${ }^{9}$ Meaning women bearing good character.

\section{References:}

Abdullah, A. (1973) The historical back ground of Pakistan and its people, Tanzeem publishers, Karachi.

Afkhaim, M. (1995) Faith and Freedom. Women's Human Rights in The Muslim World: Women, Islam and Patriarchy. Syracuse: University press. pp, 17-19

Agarwal, B. (2002) Are we not peasant too? Land Rights and Women's claims in India, Population Council, New York, America. 
Agarwal, B. (1994) Gender and command over property: A critical gap in Economic Analysis and Policy in South Asia, World Development, Vol.22.

Alam. (2007) Women Empowerment in Pakistan. in E.Mumtaz, K (eds), Women in South Asia.Vol (16) pp.6-18, South Asian Journal, Lahore, Pakistan.

Al Quran. 4:11-12, 4:176

Engles, F. (1972) (ed) The Origin of Family and Private Property and States, Lawrence and Wish Art, London.

Bernard, G. (1994) Qualitative Analysis for Social Scientists, Cambridge University press. New York, America.

Bhasin, K. (2000) Understanding Gender, Paul Press. pp, 20-22, New Delhi, India.

Bourdieu, P. (1977) An Outline of the Theory of Practice. University Press, Cambridge, pp, 67-70

Saraswati, T .S. (1999) Culture, Socialization and Human Development: Theory Research and Applications in India, Sage publication, New Delhi, India.

Dube, L. (1988) Socialization of Hindu Girls in Patrilineal India in Socialization Education and Women: Exploration in Gender identity. (ed).Ghana Karuna; Orient Longman, New Delhi, India.

Foucault. (1980) Language counter Memory, Practice, Oxford: BlackWell. Retrieved on December3, 2006 http://lucy.ukc.ac.uk/csacpub/russian/volkov.html

George. (1979) A Modern Dictionary of Sociology, Barnes and Nobel, New York, America. $\mathrm{Pp}: 245$

Hardy, Sandre. (2004), Realizing Feminist Standpoint Epistemology, Routledge Publication, New York, America.

Haroon, A. (2005) Feminism Aur Hum. in Fatima (ed) Feminism Aur Pakistani Aurat. Wada Katab Ghar, Karachi, Pakistan. pp, 14-17

Hassan, I, N. (2001) Women in Development: A Comparative Commission on Status of Women, Open University Press., Islamabad, Pakistan, Pp. 290-298 
Hesse, B. \& S. \& Naxy. (2007) Feminist Research, Sage Publication, London.

Hussain. (1994) Women as object Women as Subject with Fundamentalist In Locating the Self: Perspective on Women and Multiple Identities,(ed.)Khan, N.S, Siagol\&Zia, ASR .Lahore Publication. pp, 89-91

Jasim, S. (2001) Honor, Shame\& Resistance: Pakistani Society, Sage Publication, Lahore, Pakistan. pp, 79-86,

Kandiyoti, D. (1988) Bargaining with Patriarchy: Gender and Society. Vol (2). Sage Publication, London, Pakistan. pp, 78-87

Medhi, R. (2002) Gender and property law in Pakistan, Vanguard Publishers, Lahore, Pakistan.

Marx, K. (2002) The Protestant Ethic and the Spirit of Capitalism. Los Angles, Roxbury Company.

Mies, M. (1986) Patriarchy and Accumulation on A world Scale. Book Craft Bath limited, United Kingdom.

Mill, S, J. (1995) The Subjection of Women. Equality of Rights, Deep and Deep Publication, New Dehli, India.

Off, Link. (1989) Gender and Discourse: Gender in everyday life. Sage Publication, London. pp, 81-83,

Oakley, A. (1981) Interviewing women A contradiction in terms In H.Roberts (ed), Doing Feminist Research, Routledge and Kegan Paul. London. pp,30-61

Papanek, Hanna. (1982) Purdah: Separate Worlds and Symbolic Shelter, in Papanek, Hanna and Minault, Gail. (eds.) Separate Worlds: Studies of Purdah in South Asia, Chanakya Publications, Delhi, India. pp, 3-53

Saigol, R. (1993) Feminist and Research Methodology. Paper presented in workshop Women Studies in Pakistan, Islamabad, Pakistan.

SDPI . (2006) Land rights of women in Pakistan. Action Aid, Shrikat Gah Press.

Sen, I. (2005) Human Right's of Minority and Women: Women's Movement and Customary Law, Isha Books. Delhi, pp. 116-119 
Shah, M, A; Nasra, S. (1978) Research Method. A Handbook, Manpower Institute. Islamabad, pp, $16-17$

Shaheed, F. \& Mumtaz, K. (1978) Two Step Forward, one Step Back: Women of Pakistan, Vanguard, Lahore, Pakistan.

Shaheed, Warriach, Baluch and Gazder (ed.) (1998) Shaping of Women's Lives Shirkat Gah, Lahore, Pakistan.

Sharma, Seema. (2006) Women, Work and property in North-West India, Tavistock Publications, London and New York.

Sharma, U. (1984) Dowry in North India: Its Consequences for Women In Hirschon, R. (eds) Women and Property-Women ad Property, Canberra St. Martin's Press, New York.

Singleton, Straits \& Macalister. (1988) Approaches to Social Research: Informal and unstructured interviews, Oxford University Press.

Ulfat, A \& Chaudhry, G, M. (2007) Women and protection of women rights Print yard Printing Press, Lahore, pp.70-75

UNDP. Women's Rights of inheritance and its implementation. National Commission on Status of Women, Aligrah publication.pp, 35-36, Delhi, India.

Walby, S. (1997) Theorizing Patriarchy, Blackwell Publishers, Oxford.

Zafar, F. (1991) Legal status of women in Pakistan, Findings our Way, ASR Publication, Lahore, Pakistan.

Rabbia Aslam is a part time tutor in Department of Women Studies, Allama Iqbal Open University, Islamabad, Pakistan. She is also working as a researcher and report writer in Potohar Organization for Development Advocacy, Islamabad. 